This Tennessee State Summary educates policymakers and the public about EERE investments and their positive impacts in Tennessee.

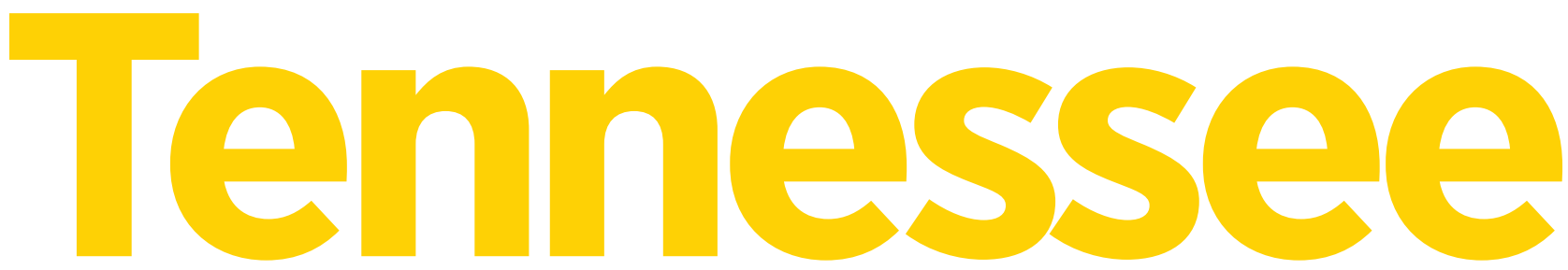

The U.S. Department of Energy (DOE) is pursuing an all-ofthe-above approach to developing every source of American energy. The Office of Energy Efficiency and Renewable Energy (EERE) leads DOE efforts to build a strong clean energy economy, a strategy that is aimed at reducing our reliance on foreign oil, saving families and businesses money, creating middle-class jobs, and reducing pollution.

This strategy will position the United States as the global leader in clean energy, increasing our nation's economic competitiveness. In 2012, \$268 billion was invested globally in clean energy, a 500\% increase since $2004 .{ }^{1}$ Trillions of dollars will be invested in the coming decades. Clean energy represents one of the most important economic development races of the 21 st century. We face a stark choice - the clean energy technologies of tomorrow can be invented and manufactured in Tennessee and the rest of the United States for domestic use and export around the world, or we can cede global leadership and import those technologies from China, India, Germany, and elsewhere.

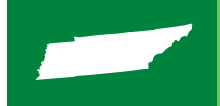

Tennessee's Clean Energy Resources and Economy

- Clean Economy Jobs (2010): 76,000+

- Average Annual Growth Rate of Clean Economy Jobs (2003-2010): 3.8\%

- Average Annual Wage of Clean Economy Jobs (\$2009): $\$ 37,347^{2}$

Tennessee has substantial clean energy resources, including biomass and hydroelectric power. Tennessee is home to two major ethanol production facilities, with a combined total capacity of 215 million gallons per year, and the state has 42 ethanol (E85) and 43 biodiesel refueling stations. ${ }^{3}$ Biomass collection in agriculture and forestry industries, refining and fuel production, distribution, and retail sales have contributed significantly to the state's economy. In 2010, Tennessee utilities invested \$49 million in energy efficiency and recorded savings of 120 million kilowatt-hours. This investment supports three loan programs and 14 utility-sponsored rebate programs for energy efficiency.

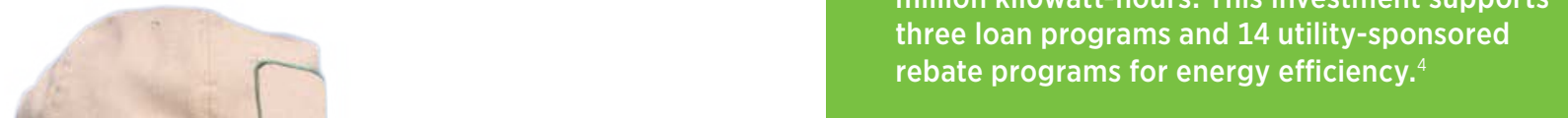




\section{EERE and Tennessee}

EERE helps create Tennessee's clean energy economy today, developing and delivering innovative, market-driven solutions for the following:

- Sustainable transportation - making transportation cleaner and more efficient through solutions that put electric drive vehicles on the road and replace oil with clean domestic fuels

- Renewable electricity generation - reducing the cost of renewable energy through solutions that squeeze more usable power from sustainable resources and improve the economics of manufacturing and installation

- Energy-saving homes, buildings, and manufacturing developing cost-effective energy-saving solutions that help make our country run better through increased efficiency_promoting better plants, manufacturing processes, and products; more efficient new homes and improved older homes; and other solutions to enhance the buildings in which we work, shop, and lead our everyday lives.

\section{EERE Investments in Tennessee}

EERE invests in Tennessee through a broad range of clean energy projects, including advanced manufacturing, biofuels, vehicles, solar, and other technologies. EERE works with public and private partners in Tennessee, most significantly DOE's Oak Ridge National Laboratory (ORNL). Through the research, demonstration, and deployment activities we conduct with ORNL and Tennessee's businesses, nonprofits, and local governments, EERE is supporting cities, communities, and families to develop innovative, cost-effective clean energy solutions.

\section{Sustainable Transportation}

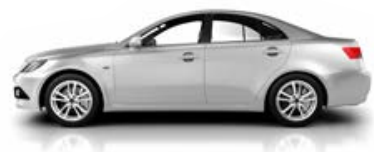

\section{Improving Advanced Biofuel Production}

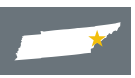

Vonore, Tennessee

EERE investment: \$5M

Partnering with Genera Energy, LLC, EERE supports efforts to overcome challenges associated with the harvest, collection, storage, and delivery of switchgrass to a one-of-a-kind cellulosic ethanol biorefinery that uses DuPont's proprietary conversion technology. The biorefinery in Vonore converts non-food biomass feedstocks - in this case, corn cobs, corn stover, other agricultural residues, and energy crops like switchgrass or biomass sorghum - into ethanol. At capacity, Genera expects that the refinery will produce 250,000 gallons of ethanol annually. These activities are a key component of the University of Tennessee's Biofuels Initiative, which includes a $\$ 70.5$ million state investment in developing a cellulosic biofuels industry and focuses on a farm fieldto-filling-station that aims to eliminate barriers across the supply chain and make advanced biofuels more available and affordable to the consumer. ${ }^{5}$

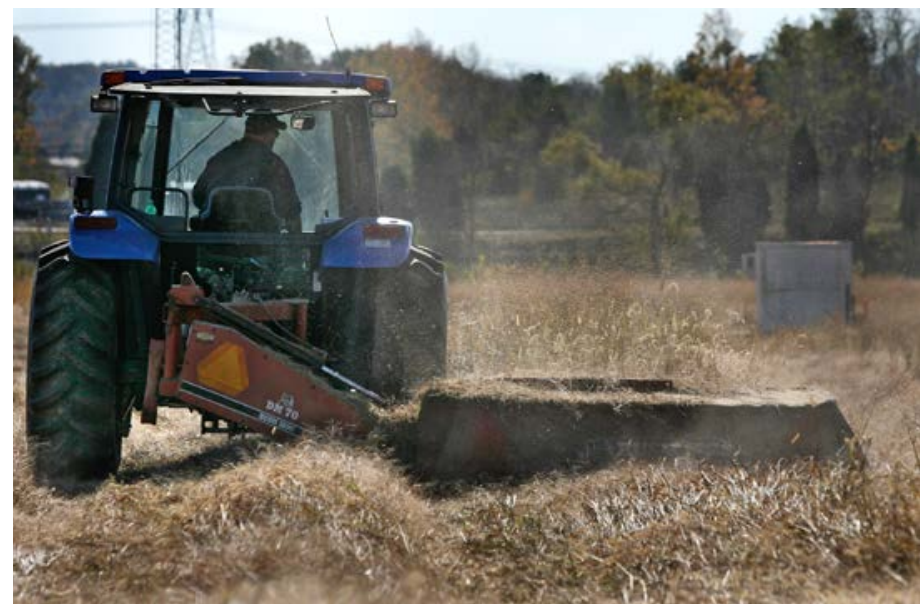

Switchgrass, studied at Oak Ridge National Laboratory for its biofuel potential, being harvested. Photo from Oak Ridge National Laboratory

\section{Adopting Smart Transportation Solutions}

East and Middle Tennessee

EERE investment: $\$ 30 \mathrm{~K}$ annually to each coalition

EERE coordinates a network of nearly 100 Clean Cities coalitions - self-organized groups of local community, government, and business stakeholders whose efforts to adopt smart transportation solutions have displaced more than 4.5 billion gallons of gasoline and diesel since 1993. Tennessee is home to two Clean Cities coalitions: East Tennessee Clean Fuels Coalition and Middle Tennessee Clean Cities. In 2011, these two coalitions reduced fuel consumption by the equivalent of nearly 6.5 million U.S. gallons of gasoline and prevented nearly than 50,000 tons of greenhouse gas emissions. Together, the coalitions include nearly 250 businesses, local governments, and other organizations, and work to promote the use of the more than 900 alternative fuel and charging stations in Tennessee. In 2011, the two coalitions leveraged DOE's support to raise more than $\$ 400,000$ from businesses, local governments, other organizations, and non-DOE grants. 


\section{Renewable Electricity Generation}

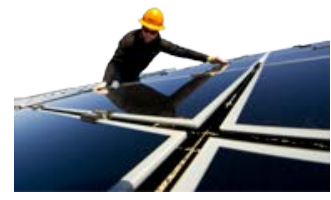

\section{Building Solar Infrastructure}

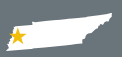

Haywood County, West Tennessee Solar Farm

EERE investment: \$31M

In providing \$31 million to build the West Tennessee Solar Farm (WTSF), EERE supported the University of Tennessee in building the largest photovoltaic installation in the seven-state Tennessee Valley Authority region. WSTF has operated since early 2012 and has the capacity to provide up to 5 megawatts of energy, which is enough to power up to 500 homes. More than 200 workers installed more than 20,000 solar panels - made by a U.S. manufacturer - and connected the array to the grid. This project is also part of Tennessee's Volunteer State Solar Initiative, a solar energy and economic development program that focuses on job creation, education, renewable power production, and technology commercialization.

\section{Energy-Saving Homes, Buildings, and Manufacturing}

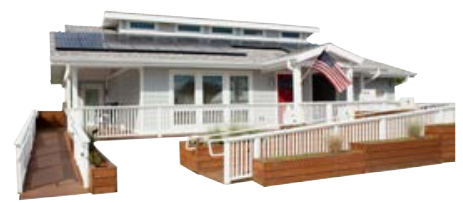

\section{Working with Oak Ridge National Laboratory to Impact U.S. Industry}

Oak Ridge, Tennessee

EERE works with ORNL to enable innovations in advanced manufacturing, buildings, and transportation, such as:

\section{- Most Efficient Ground-Source Integrated Heat Pump Technology Is Now on the Market}

ClimateMaster and ORNL partnered in 2008 to develop a ground-source integrated heat pump that provides space conditioning and water heating in residential applications. These heat pumps are 33\% more efficient than other geothermal heat pumps available on the market. The path to this innovation began in 2005, when EERE challenged ORNL to partner with industry to develop products that could provide space conditioning and hot water needs while consuming at least $50 \%$ less energy than conventional minimum efficiency equipment The ClimateMaster heat pump was recognized at the 2013 Air Conditioning, Heating, and Refrigeration (AHR) Exposition-receiving a first place AHR Innovation Award in the heating category. ${ }^{6}$

\section{- Highly Efficient Water Heater Technology Brings Jobs Back to America}

General Electric (GE) and ORNL partnered to finalize and test the performance of the company's GeoSpring ${ }^{\mathrm{TM}}$ highly efficient water heater, which, compared to standard models, pays for itself in less than 2.5 years when compared to standard models. GE's prototype for the GeoSpring ${ }^{\mathrm{TM}}$ water heater was inspired by DOE research efforts. GE opened a new plant - the first to open in the Louisville Appliance Park in more than 50 years- to manufacture the water heater, through a revitalization that was partially funded through a manufacturing tax credit provided under the American Recovery and Reinvestment Act. The new plant allowed GE to move manufacturing operations back to the United States from China, where a former version of the appliance was made, creating hundreds of jobs. ${ }^{7}$

\section{- Aluminum Impellers for Diesel Engine Turbo Chargers Are Cheaper, Faster, and More Energy Efficient}

Queen City Forging and ORNL entered into an agreement supported by EERE to deploy a rapid infrared heating technology developed at ORNL to produce aluminum components for diesel engine turbochargers. Typically, due to the harsh demands of the engine environment, these engine components are made using titanium. The rapid infrared heating technique enhanced the fatigue properties of aluminum, allowing the company to replace of the titanium components that cost 10 times as much to produce. Queen City Forging is rapidly approaching 2 million aluminum components sold - a major portion of the company's revenue.

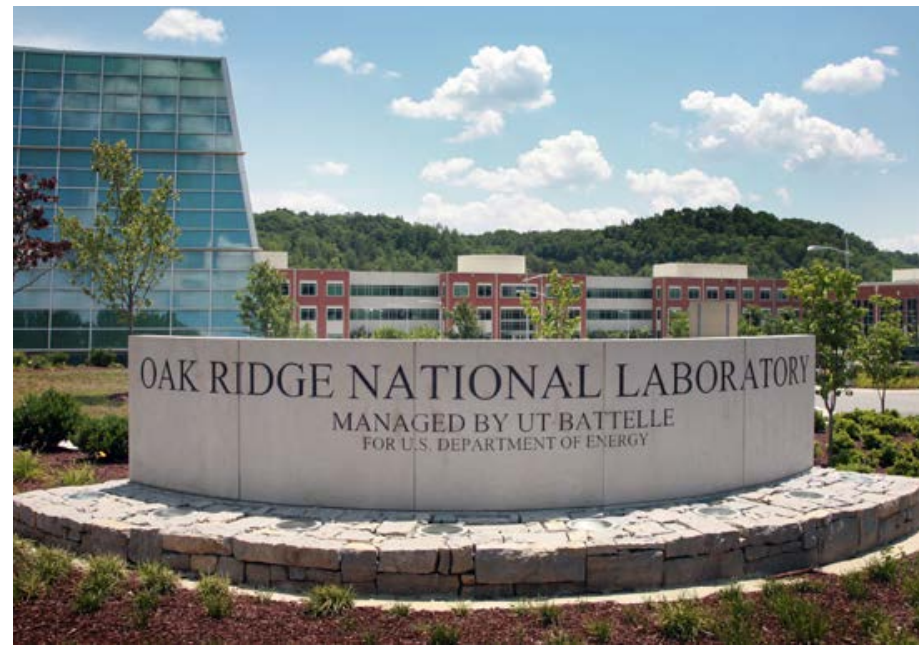

Oak Ridge National Laboratory, located in Oak Ridge, Tennessee, works with EERE to advance energy-efficient technologies. The lab's research and development activities are helping to lead the United States toward energy independence. Photo from Oak Ridge National Laboratory 
- Easily Applied Coatings Extend Equipment Lifetimes, Improve Productivity, and Generate Energy Savings for Many Products

ORNL and ROSS Technology, Inc. received funding and support from EERE to work together to develop a new class of nanostructured, super hydrophobic powder coatings that significantly extend equipment lifetimes, improve productivity, and generate substantial energy savings for various industrial, transportation, and consumer products. The coating technology is already patented with its first license issued to ROSS. For three potential markets - motors and pumps, water transportation, and steel corrosion - these coatings have the potential to yield a cost savings of $\$ 1.74$ billion per year and reduce carbon pollution by 6.16 million tons per year.

\section{- Ford-Dow Partnership Is Linked to Carbon Fiber Research at ORNL}

EERE provided funding to Dow Chemical, Ford Motor

Company, and ORNL to develop cutting-edge manufacturing processes that will save the companies money by reducing the energy needed to power their facility operations. These funds support EERE's strategy of investing in emerging technologies that create highquality, domestic manufacturing jobs and enhance the competitiveness of U.S. companies in today's global markets. ORNL brokered the partnership between two of its strategic partners, Ford Motor Company and Dow Chemical. This led to the announcement in April 2012 of a joint development agreement to establish low-cost, automotive-grade carbon fiber and develop component manufacturing methods for high-volume automotive applications, building on years of EERE and ORNL research support. The partnership will seek to combine the best of Ford's capabilities and experience in design, engineering, and high-volume vehicle production with Dow's strengths in research and development, materials science, and high-volume polymer processing.

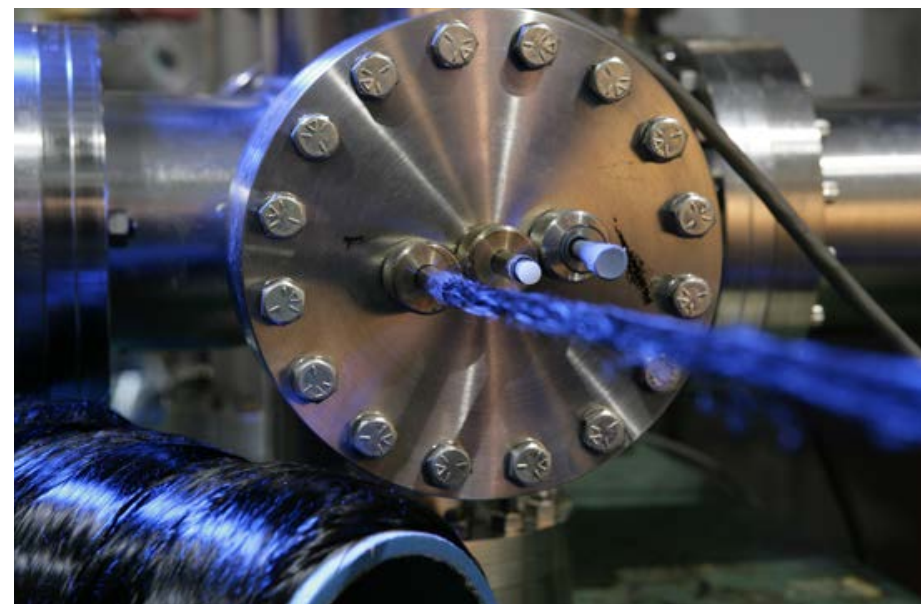

Carbon fiber research can enable the development and commercialization of stronger lighter-weight materials for a variety of clean energy technology. Photo from Oak Ridge National Laboratory

\section{- MA3T Model Development at Oak Ridge National} Laboratory Assesses the Future of Fuel Cell Markets

Leveraging EERE funding, ORNL has developed a model for simulating the market potential of fuel cell electric vehicles and challenges to achieving success over time, including competition with established vehicle technologies. The MA3T (Market Acceptance of Advanced Automotive Technologies) Model is a nested, discrete choice model with more than 1,000 market segments that estimates future market share based on the supply of hydrogen fuel, fuel cell electric vehicle manufacturing, and consumer demand to simulate the transition of lightduty vehicle transportation to hydrogen. It also has the capability to assess the penetration of advanced vehicle technologies, including fuel cells, into the conventional light-duty vehicle fleet. 


\section{Better Buildings Partnerships Help America's Commercial and Industrial Buildings Become At Least 20\% More Efficient over the Next Decade}

The United States spends about \$200 billion each year just to power commercial buildings and another approximately \$200 billion to power manufacturing facilities. The Better Buildings Challenge was launched to help America's commercial and industrial buildings become at least $20 \%$ more efficient over the next decade. To achieve this aggressive target, EERE is working with leading public and private sector partners to implement energy-saving practices that reduce energy waste, save money, and create jobs. ${ }^{8}$ Tennessee is home to several showcase projects that will provide best practices and successful models for possible replication across the country to help drive dramatic advancements in energy efficiency.

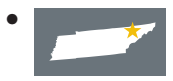

\section{Wyndham Worldwide}

Fairfield Glade, Tennessee

Wyndham Worldwide is one of the world's largest hospitality companies, offering customers a suite of hospitality services and products in lodging, vacation exchange, and rentals and vacation ownership. The company made the Better Buildings commitment to improve the energy efficiency of 10 million square feet of its properties. Wyndham is highlighting improvements to the Wyndham Resort at Fairfield Glade to demonstrate its progress.

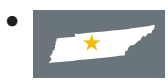

Nissan North America, Inc.

Smyrna, Tennessee

Nissan North America made the Better Buildings commitment through the Better Plants component of the challenge, aiming for a $25 \%$ reduction in energy use in its three U.S. plants by 2020 . This reduction would affect 12 million square feet of plant space. Nissan is currently building a new paint plant in Smyrna, Tennessee, that will improve energy efficiency by $30 \%$ compared to the plant it is replacing.

\section{Schneider Electric \\ Smyrna, Tennessee}

Schneider Electric has committed to reduce energy consumption in 26 plants through the Better Plants Challenge. Schneider is a global specialist in offering integrated solutions across multiple market segments, including energy and infrastructure, industrial processes, building automation, and data centers/networks, as well as in residential applications. The company's showcase project includes pursuing Superior Energy Performance certification in Smyrna, Tennessee, at a plant site that includes a recently installed 1,000-kilowatt dual voltage solar farm, providing an opportunity for more efficient solar farm operation.

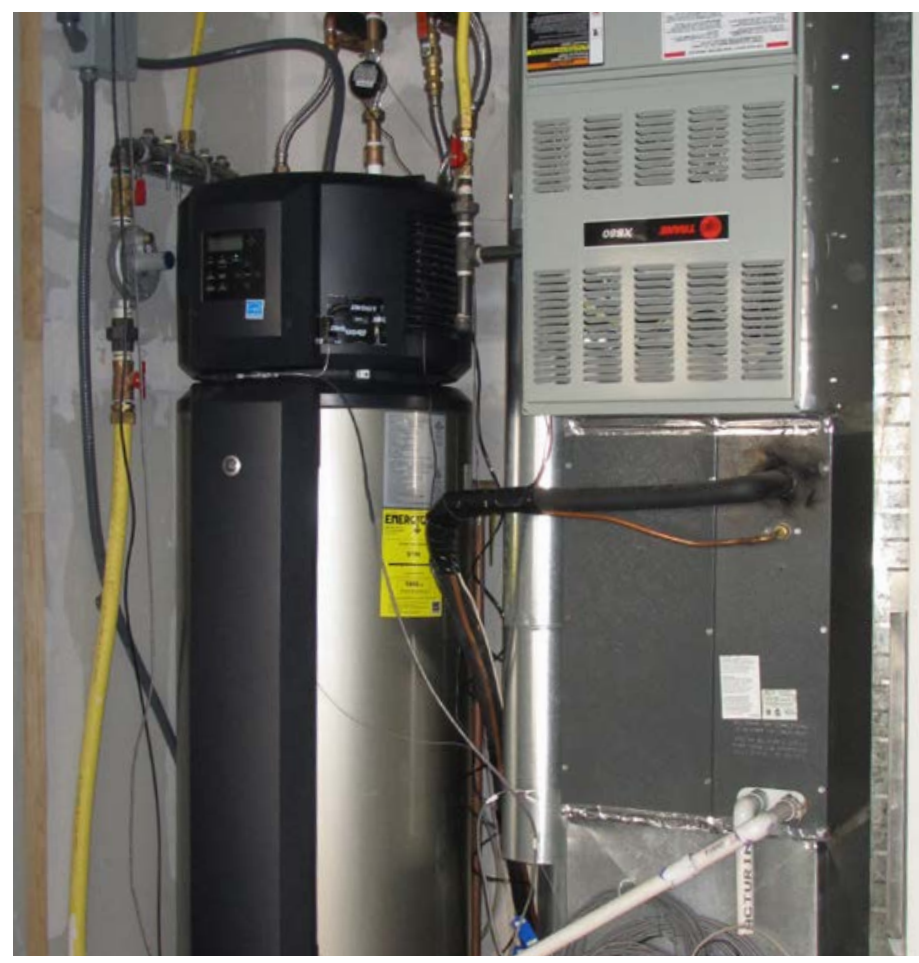

Developed in cooperation with Oak Ridge National Laboratory, GE's highly efficient GeoSpringTM water heater pays for itself in less than 2.5 years compared to a standard water heater. Photo by Ed Hancock, NREL 23100 


\section{Deploying Clean Energy Solutions in Tennessee Communities}

EERE invests in the deployment of energy efficiency and renewable energy projects in communities across the Volunteer State, catalyzing economic development, creating jobs, generating clean energy, and reducing utility bills. Of the more than \$220 million in American Recovery and Reinvestment Act (ARRA) funds allotted to the State of Tennessee from EERE specifically for deployment projects, more than 96\% has been spent through March 2013 through the Energy Efficiency and Conservation Block Grant Program, State Energy Program, and Weatherization Assistance Program. ${ }^{9}$

\section{Building Clean Energy Infrastructure}

With financial and technical support from EERE, energy officials at the state level and in 28 communities have selected and overseen the completion of hundreds of projects that are delivering the benefits of clean energy to citizens throughout Tennessee. EERE allocated more than $\$ 121$ million in ARRA funds to support activities that

- Increased energy efficiency and cost savings for approximately 4,200 buildings (almost 12 million square feet) through building retrofits

- Installed more than 180 renewable energy systems, with a total capacity of more than 14,000 kilowatts of solar energy systems

- Funded more than 200 workshops teaching more than 4,000 people to perform energy audits and install renewable energy systems

- Installed nearly 2,300 energy-efficient streetlights and more than 8,000 energy-efficient traffic signals. ${ }^{10}$

In conducting these activities, the state leveraged its funding to develop a comprehensive solar energy and economic development program, focusing on job creation, education, renewable power production, and technology commercialization. In this process, two grant programs were developed to encourage growth of the state's solar industry.

\section{Weatherizing Homes for Lower Income Families}

Tennessee has spent more than $98 \%$ of the more than $\$ 99$ million it received in ARRA funds to weatherize more than 19,000 homes, exceeding its goal. This resulted in annual energy savings of more than 550 billion British thermal units, averting more than 50,000 metric tons of carbon pollution to date, the equivalent of taking more than 10,000 passenger vehicles off the road for a year. The projects have enabled income-eligible families to save hundreds of dollars per year on heating and cooling bills by improving their homes' energy efficiency, as well as the health and safety of home environments. ${ }^{11}$

\section{Deployment Project Examples}

\section{Upgrading Homes to Save Families Money}

Memphis, Tennessee

EERE Investment: $\$ 2.5 \mathrm{M}$

The City of Memphis improved the energy efficiency of affordable, owner-occupied housing by conducting energy audits to identify and implement energy improvements for heating and cooling, windows, insulation, and other items at no cost to the qualified homeowner. On average, Memphis homes have very low efficiency, with annual household electricity use at $42 \%$ above the U.S. average. The initiative exceeded its goals dramatically, upgrading more than 1,800 homes, which totaled 2.5 million square feet.

\section{Revitalizing a Historic Landmark}

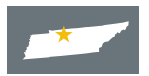

Nashville, Tennessee

EERE Investment: $\$ 583 \mathrm{~K}$

The City of Nashville installed a geothermal heat pump system at the historic NABRICO Building on the Nashville Riverfront. This freed up local funds needed to complete the building's extensive interior renovations. Thanks to the building's renovations, the city is pursuing Leadership in Energy and Environmental Design platinum certification for energy efficiency and keep public future energy costs low.

\section{Reducing Energy Consumption}

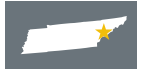

\section{Blount County, Tennessee \\ EERE Investment: \$300K}

Blount County is saving its taxpayers money by undertaking three specific activities to expand the use of renewable energy and improve energy efficiency. The county installed a solar thermal water-heating system at its justice center, where it also retrofitted the detention facility's existing gas-powered water-heating system. Funding will also be used to retrofit county buildings with occupancy sensor lighting that automatically switches off when occupants leave their space. ${ }^{12}$ 
"Who's Winning the Clean Energy Race” Pew Charitable Trust, 2011. http://www.pewtrusts.org/uploadedFiles/wwwpewtrustsorg/Reports/Clean Energy/ Clean\%20Energy\%20Race\%20Report\%202012.pdf.

2"Sizing the Clean Economy: The Clean Economy in the State of Tennessee." The Brookings Institution and Battelle, July 2011. http://www.brookings.edu/ /media/Series/ Clean\%20Economy/47.pdf.

3"Alternative Fueling Station Counts by State." EERE Alternative Fuels Data Center, September 2012. http://www.afdc.energy.gov/fuels/stations_counts.html.

4“State Energy Efficiency Policy Database." American Council for an Energy-Efficient Economy, 2012. http://aceee.org/energy-efficiency-sector/state-policy/Tennessee/214/all/191.

${ }^{5}$ Campbell, Dan. "Switchgrass Plant.” Genera Energy, 2011. http://www.generaenergy.com/ wp-content/uploads/Genera_RuralCooperativesMag1.pdf.

6"Integrated Biorefineries: Biofuels, Biopower, and Bioproducts." EERE Biomass Program July 2012. http://www1.eere.energy.gov/biomass/pdfs/ibr_portfolio_overview.pdf.

7"DOE Highlights New GE Appliance Factory in Kentucky Supported by the Recovery Act." EERE News, February 2012. http://apps1.eere.energy.gov/news/progress_alerts.cfm/ pa_id $=677$.

s"Better Buildings Challenge Continues to Grow." (June 2012). http://energy.gov/articles/ better-buildings-challenge-continues-grow.

${ }^{9}$ As of March 31, 2012, Tennessee received $\$ 204$ million of ARRA funds of which the State had spent \$192 million

${ }^{10}$ Tennessee received $\$ 104.7$ million through EERE's EECBG Program ( $\$ 42.2$ million) and EERE's State Energy Program (\$62.5 million). As of March 31, 2012, Tennessee has spent $\$ 35.9$ million of the $\$ 42.2$ million the state received in ARRA funds through EERE's EECBG Program, and it has spent $\$ 59$ million of the $\$ 62.5$ million it received in ARRA funds through EERE'S SEP.

11"Residential Energy Consumption Survey." U.S. Energy Information Administration, 2009 http://www.eia.gov/consumption/residential/data/2009/.
12“Solar and Energy Efficiency Justice." EERE, June 2010. http://energy.gov/articles/ solar-and-energy-efficiency-justice.

13“"Retrospective Benefit-Cost Evaluation of U.S. DOE Vehicle Combustion Engine R\&D Investments: Impacts of a Cluster of Energy Technologies." DOE, May 2010. http://wwwl.eere.energy.gov/analysis/pdfs/advanced_combustion_report.pdf.

14"Retrospective Benefit-Cost Evaluation of DOE Investment in Photovoltaic Energy Systems." DOE, August 2010. http://www1.eere.energy.gov/analysis/pdfs/solar_pv.pdf.

15“Retrospective Benefit-Cost Evaluation of U.S. DOE Wind Energy R\&D Program," DOE, June 2010. http://www1.eere.energy.gov/analysis/pdfs/wind_bc_report10-14-10.pdf.

${ }^{16}$ National Research Council. Energy Research at DOE: Was It Worth It? Energy Efficiency and Fossil Energy Research 1978 to 2000. Washington, DC: National Academies Press, 2001

17"DOE Hydrogen and Fuel Cells Program Record \#12020," DOE, September 27, 2012 http://hydrogen.energy.gov/pdfs/12020_fuel_cell_system_cost_2012.pdf. Based on projections to high-volume manufacturing.

18 "Retrospective Benefit -Cost Evaluation of DOE Investment in Photovoltaic Energy Systems." DOE, August 2010. http://www1.eere.energy.gov/analysis/pdfs/solar_pv.pdf.

19"Retrospective Benefit-Cost Evaluation of U.S. DOE Wind Energy R\&D Program," DOE, June 2010. http://www1.eere.energy.gov/analysis/pdfs/wind bc report10-14-10.pdf.

20"Weatherization Assistance Program." EERE, May 2009. http://www1.eere.energy.gov/wip/ pdfs/wap_factsheet.pdf.

21"Building Technologies Program: History and Impacts." EERE, 2013. http://www1.eere.energy.gov/buildings/appliance_standards/history_and_impact.html.

22" "Energy Technology Solutions: Public-Private Partnerships Transforming Industry." EERE, December 2010. http://www1.eere.energy.gov/manufacturing/pdfs/itp_successes.pdf.

23“Facilitating Cost-Effective Federal Energy Management." EERE, December 2012 http://www1.eere.energy.gov/femp/pdfs/femp_fs.pdf. 


\section{A Proven Track Record}

\section{Snapshot of National Outcomes from EERE Investments}

- EERE's $\$ 931$ million investment in vehicles combustion engine R\&D from 1986 to 2007 achieved a net benefit of $\$ 69$ billion (2008 dollars) in fuel savings for users of heavy-duty diesel trucks. ${ }^{13}$

- EERE's \$3.7 billion investment in solar photovoltaic R\&D from 1975 to 2008 resulted in a net economic benefit of \$15 billion (2008 dollars) due to module efficiency and reliability improvements. ${ }^{14}$

- EERE's $\$ 1.7$ billion investment in wind energy R\&D from 1976 to 2008 resulted in a net economic benefit of \$8.7 billion (2008 dollars) due to wind turbine efficiency, energy capture, and reliability improvements. ${ }^{15}$

- A 2001 National Academy of Sciences analysis found that investments of \$1.6 billion in energy efficiency R\&D in the first two decades of DOE's existence from 1978 to 2000 realized a net economic benefit of approximately $\$ 30$ billion (1999 dollars). ${ }^{16}$

Sustainable Transportation

- EERE research has helped reduce production costs of automotive lithium-ion batteries by more than $50 \%$ since 2008 and is on track to reach its goal of enabling cost-competitive market entry of plug-in hybrid electric vehicles within the next 10 years.

- EERE's activities to achieve cost-competitiveness for biofuels have resulted in the recent achievement of reaching a modeled cellulosic ethanol production cost of $\$ 2.15$ per gallon of ethanol (or \$3.27 per gallon of gasoline equivalent).

- EERE's efforts have reduced the projected costs of automotive fuel cells (assuming high-volume manufacturing) by more than $35 \%$ since 2008 and $80 \%$ since 2002-doubling the durability of fuel cells from 950 hours of demonstrated operation in 2006 to more than 2,500 hours of operation on the road. ${ }^{17}$

\section{Renewable Electricity Generation}

- Without EERE involvement, the average solar photovoltaic (PV) module production cost per watt would have been $\$ 5.27$ in 2008, rather than \$1.92. EERE has accelerated solar industry progress by an estimated 12 years. ${ }^{18}$

- Without EERE involvement, cumulative wind power deployment through 2008 would have been less than a third of actual 2008 levels. EERE has accelerated the overall progress of the wind industry by an estimated 6 years. ${ }^{19}$

- More than 6,200,000 homes have been weatherized with EERE funding provided to states or leveraged from other sources with EERE support since 1976-creating an average energy savings of \$350 or more per year and avoiding \$1.6 billion in energy costs during winter 2005 alone for all households weatherized. ${ }^{20}$

- Due to EERE appliance standards implemented through 2012, a typical household today already saves about $\$ 180$ per year off its utility bills. Households can expect to save more than $\$ 300$ per year by 2030 , as they replace their existing appliances with newer models that use less energy - a cumulative savings to consumers of more than $\$ 900$ billion by 2020 , and more than $\$ 1.6$ trillion through 2030 . The cumulative energy savings of these standards phased in through 2012 will be about 70 quadrillion British thermal units (quads) of energy through 2020, and will amount to 120 quads through 2030. (The United States consumes a total of about 100 quads of energy per year.) ${ }^{21}$

- EERE and its partners in the manufacturing sector have successfully launched 220 new, energy-efficient technologies, received 78 R\&D 100 Awards, and delivered technical assistance to more than 33,000 industrial plants. ${ }^{22}$

- Since 2005, EERE has facilitated $\$ 3.1$ billion of efficiency investments in federal government facilities from performance-based contracts, which will result in energy cost savings of approximately $\$ 8.5$ billion over the life of the energy-saving measures. The savings on utility bills and operation and maintenance created through the facility upgrades will be used to pay for the project over the term of the contract, and the agencies will continue to save money and energy after the contract term has ended. ${ }^{23}$

The Office of Energy Efficiency and Renewable Energy is at the center of creating the clean energy economy today. We lead U.S. Department of Energy efforts to develop and deliver market-driven solutions for renewable electricity generation; sustainable transportation; and energy-saving homes, buildings, and manufacturing. To learn more about the activities of the Office of Energy Efficiency and Renewable Energy, visit eere.energy.gov. If you have questions or comments about the information in this document, please contact us at EE.Communications@ee.doe.gov.

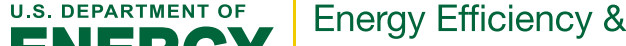 ENERGY Renewable Energy}

